\title{
Nanostructures of PAMAM Dendrimers in Drug Delivery System for 5-Fluorouracil
}

\author{
Fatemeh Haghighi ${ }^{a}$, Ali Morsali*a,b, \\ Mohammad R. Bozorgmehr a and S. Ali Beyramabadi ${ }^{a}$ \\ ${ }^{a}$ Mashhad Branch, Islamic Azad University \\ Mashhad, Iran \\ ${ }^{b}$ Research Center for Animal Development Applied Biology, \\ Mashhad Branch, Islamic Azad University \\ Mashhad 917568, Iran
}

Received 21.05.2020, received in revised form 17.08.2020, accepted 09.09.2020

\begin{abstract}
In this article, we studied five noncovalent structures for adsorption of 5 fluorouracil drug (5 FL) on poly(amidoamine) G0 generation dendrimer (PAMAMG0) carrier using M06-2X and B3LYPfunctionals. We investigate the quantum molecular descriptors and the binding and solvation energies in gas phase and aqueous solution. The energetic stability of non-bonded species (PAMAMG0/5-FL1-5) was shown through evaluation of binding free energies. The solvation free energies of PAMAMG0/5-FL1-5 are negative, indicating that the solvation process is spontaneous. We considered quantum molecular descriptors such as electrophilicity power and global hardness and found reduced toxicity of 5-FL drug near PAMAMG0 carrier as well as facilitated drug release. The AIM (Atoms In Molecule) analysis for all PAMAMG0/5-FL1-5 structures demonstrated that the pseudo-hydrogen and hydrogen bonds are essential in the functionalization of PAMAMG0 with 5-FL drug. We found thatthe structure in which 5-FL drug interacts with $\mathrm{CO}$ functional groups of PAMAMG0 is the most stable configuration.
\end{abstract}

Keywords: poly(amidoamine) dendrimer, 5-fluorouracil, nanomedicine, hydrogen bonding, DFT.

Citation: Haghighi F., Morsali A., Bozorgmehr M.R., Beyramabadi S.A. Nanostructures of PAMAM dendrimers in drug delivery system for 5-fluorouracil, J. Sib. Fed. Univ. Chem., 2020, 13(3), 309-323. DOI: 10.17516/1998-2836-0184

(C) Siberian Federal University. All rights reserved

This work is licensed under a Creative Commons Attribution-NonCommercial 4.0 International License (CC BY-NC 4.0).

* Corresponding author E-mail address: almorsali@yahoo.com; morsali@mshdiau.ac.ir 


\title{
Наноструктуры дендримеров ПАМАМ \\ в системе доставки лекарств для 5-фторурацила
}

\author{
Ф. Хагигия ${ }^{\mathrm{a}}$ А. Морсали ${ }^{\mathrm{a}, \boldsymbol{\sigma}}$, \\ М.Р. Бозоргмехр ${ }^{\text {a }, ~ С . А . ~ Б е и ̆ р а м а б а д и ~}{ }^{\mathrm{a}}$ \\ ${ }^{a}$ Мешхедский филиал \\ Иран, Мешхед \\ ${ }^{6}$ Исследовательский цзентр \\ прикладной биологии развития животных \\ Мешхедский филиал, Исламский университет Азад \\ Иран, Мешхед
}

Аннотация. В этой статье мы изучили пять нековалентных структур для адсорбции лекарственного средства 5-фторурацила (5 FL) на носителе дендримеров поколения поли (амидоамина) G0 (PAMAMG0) с использованием функционалов M06-2Х и B3LYP. Мы исследуем квантовые молекулярные дескрипторы и энергии связывания и сольватации в газовой фазе и водном растворе. Энергетическая стабильность несвязанных частиц (PAMAMG0 / 5-FL1-5) была показана путем оценки свободных энергий связи. PAMAMG0 / 5-FL1-5 отрицательны, что указывает на самопроизвольный процесс сольватации. Мы рассмотрели квантовые молекулярные дескрипторы, такие как мощность электрофильности и общая жесткость, и обнаружили сниженную токсичность препарата 5-FL вблизи носителя PAMAMG0, а также облегчение высвобождения лекарства. Анализ AIM (атомы в молекуле) для всех структур PAMAMG0 / 5-FL1-5 продемонстрировал, что псевдоводородные и водородные связи важны для функционализации PAMAMG0 лекарственным средством 5-FL. Мы обнаружили, что структура, в которой препарат 5-FL взаимодействует с функциональными группами CO PAMAMG0, является наиболее стабильной конфигурацией.

Ключевые слова: поли (амидоамин) дендример, 5-фторурацил, наномедицина, водородная связь, DFT.

Цитирование: Хагигия, Ф. Наноструктуры дендримеров ПАМАМ в системе доставки лекарств для 5-фторурацила / Ф. Хагигия, А. Морсали, М.Р. Бозоргмехр, С.А. Бейрамабади // Журн. Сиб. федер. ун-та. Химия, 2020. 13(3). С. $309-323$. DOI: $10.17516 / 1998-2836-0184$

\section{Introduction}

An attempt to alleviate the side effects of anticancer medications, a bulk of experimental and theoretical research has recently concentrated on carbon-based carriers such as dendrimers [1], drugpolymer conjugates [2], liposomes [3], C60 [4, 5], carbon nanotubes [6-8] and polymeric micelles [9]. One of the method of drug delivery is the use of micro and nano sized particles [10]. Utilization of dendrimers as a host for different molecules, such as drugs, and investigation of the role of hydrogen bonding in these drug delivery systems were started in 1995 [11, 12]. With ahighly symmetric structure, 
dendrimers have well-defined nanostructure [13]. In fact, dendrimers describe a family of synthetic polymers that are highly branched three-dimensional structures in nature. The word dendrimer comes from the Greek word "Dendron" meaning tree; it gives a clear description of their unique structure that represents a tree-like branch [14].

Generally, a dendrimer consists of three parts; (a) a basic core that contains two or more reactive groups; (b) interior layers made up of recurring branching units that are covalently bonded to the core; and (c) terminal functional groups that are located on the outer surface [14]. The peripheral surface group is able to define the nature of dendrimer and forges bonds with branched units related to each generation. Depending on the core, 3 or 4-branched units are added to dendrimer core to create the first generation and then the two other branched units are added to each monomer of former generation to produce the second generation. Therefore, dendrimer diameters increase linearlyalong with an exponential growth of terminal functional groups by the addition of shells or generation [15].

Given that their physico-chemical properties are markedly different from classic polymers, they are often perceived as a distinct class of molecules. This disparity has its origin in three key properties: monodispersity, multivalency, and globular shape [16]. Based on the shape of dendrimer, it is possible to determine the specific binding of functional groups on the surface and the interior structure of dendrimer. Dendrimers are mainly found in two shapes: i) spherical shape, ii) ellipsoid shape [15]. The spherical structure together with empty spaces and a high-density functional group (like amine and carboxyle group) on the surface of dendrimer facilitatethe solubility of hydrophobic drug, control the release of drug and foster the suitability of dendrimer for desired theranostic purpose [17]. The solubility of dendrimer is determined by a number of factors such as surface functional groups, repeated units, dendrimer generation, and even the core [18].

These molecules have broad applications such asdrug delivery where dendrimer nanoparticles are infused with therapeutics and target specific tissues or gene delivery which is similar to drug delivery [19]. When dendrimers are used as the nanocarriers, lower dosages of anticancer drugs are needed, which in turn would alleviate the side effects of the medicine [20-22]. Dendrimers serve as carriers for various anticancer drugs such as 5 -fluorouracil [23], cisplatin [24, 25], doxorubicin [26-28], famotidine [29], methotrexate [30], nifedipine [31], paclitaxel [32, 33], 10-hydroxycamptothecin [34], 7-butyl-10-aminocamptothecin [35], etoposide [36], artemisinin [37], flutamide [38], melphalan [39], gemcitabine [40], capecitabine [41] and 6-mercaptopurine [42]. Dendrimers havealso been used against human immunodeficiency viruses(HIV) [43-45], Alzheimer's disease [46, 47], prion diseases [48, 49], inflammation [50-52] and bacteria [53-55]. Quantum computing provides a powerful instrument for the analysis of drug delivery and other systems [56-63]. Fluorouracil (5-FU) that is found under the brandAdrucil, is an anticancer drugused for esophageal, colon, stomach [64] breast, pancreatic, and cervical cancers [64]. Moreover, as a cream it is utilized for basal cell carcinoma, actinic keratosis and skin warts [65]. In this paper, quantum chemical calculations were applied to investigate the hostguest interactions of PAMAMG0 generation dendrimer with 5-fluorouracil drug.

\section{Computational method}

First, we used GAUSSIAN 09 package $[66,67]$ for the optimization of all structures in solution and gas phases at B3LYP/6-31G(d,p) and M06-2X/6-31G(d,p). Polarized continuum model (PCM) 
$[68,69]$ was employed the implicit solvent effects. Herein, we used the standard convergence criteria for the optimization of molecular structures. We optimized all degrees of freedom for all species. In addition, frequency calculations were performed to apply thermal corrections.

For assessing chemical reactivity and stability, the quantum molecular descriptors were used. Global hardness $(\eta)$ exhibits the resistance of one particle against the modification in its electronic structures:

$$
\eta=\frac{(1-A)}{2}
$$

In which $A=-E_{L U M O}$ and $I=-E_{\text {HOMO }}$ are the electron affinity and the ionization potential, respectively. Evaluating electrophilicity index index $(\omega)$ is performed by the following formula [70]:

$$
\omega=\frac{(1+\mathrm{A})^{2}}{8 \eta}
$$

Using the QTAIMs (Quantum Theory of Atoms in Molecules) calculations, the hydrogen bondswere studied. For performing QTAIM, we used the AIMII software [71]. QTAIM dependson topological parameterssuch aselectron density $\rho(\mathrm{r})$ [72]. We concentrate on different values of electron density such as $V_{b}$ (potential energy density), $H_{b}$ (total energy density), $G_{b}$ (kinetic energy density), and $\nabla^{2} \rho$ (Laplacian of electron density) at a critical point (BCP) to recognize the nature of the bond in various species.

\section{Results and exchanges}

Figure 1 shows the optimized structures of Poly(amidoamine) G0 generation dendrimer (PAMAMG0) and 5-fluorouracil (5-FL). We studied the interaction of 5-FLincluding $\mathrm{CO}$ and $\mathrm{NH}$ functional groups with PAMAMG0 nanoparticles in 5 different ways (PAMAMG0/5-FL1-5). The optimized configurations of PAMAMG0/5-FL1-5 are shown in Fig. 2 (at M06-2X / 6-31G** in aqueous solution).

Binding (interaction) free energies $\left(\Delta G_{\text {binding }}\right)$ were calculated using the following equation:

$$
\Delta G_{\text {binding }}=\text { GPAMAMG0/5-FL1-5 - (GPAMAMG0+G5-FL). }
$$
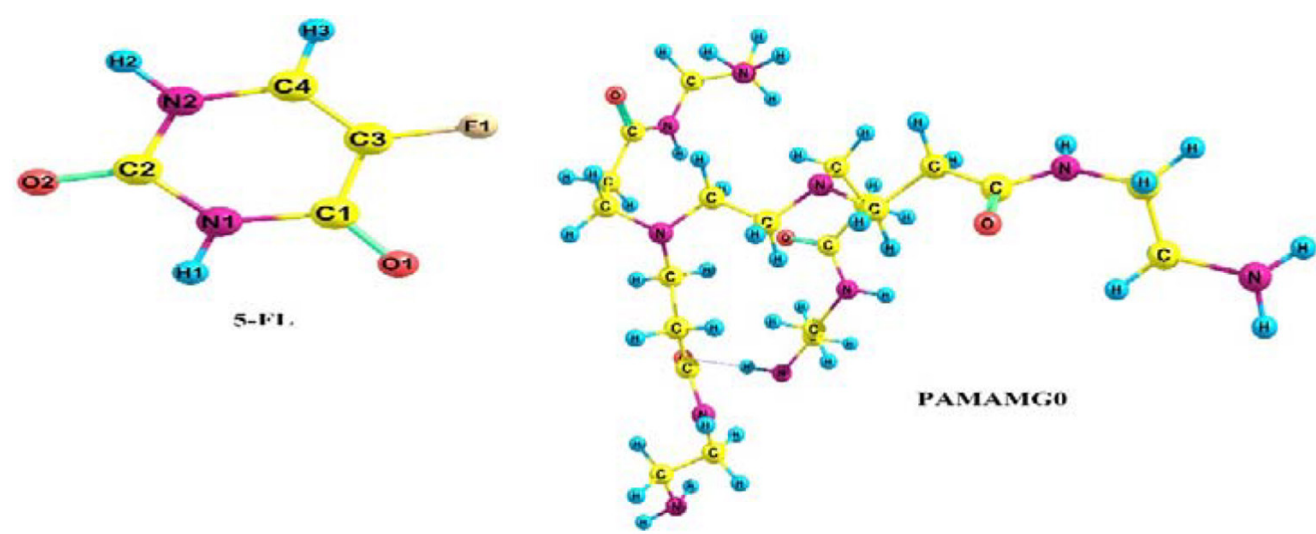

Fig. 1. Optimized structures of 5-FL and PAMAMG0 
$G_{\text {binding }}$ values at M06-2X and B3LYP levels in gas phase and aqueous solution are shown in Table 1. Contrary toB3LYP, M06-2X functional considers dispersion corrections [73]. The values of $G_{\text {binding }}$ in aqueous solution (-41. $3 \mathrm{~kJ} \mathrm{~mol}^{-1}$ and $-49.0 \mathrm{~kJ} \mathrm{~mol}^{-1}$ on average at B3LYP and M06-2X) are more positive than those of gas phase $\left(-57.4 \mathrm{~kJ} \mathrm{~mol}^{-1}\right.$ and $-51.3 \mathrm{~kJ} \mathrm{~mol}^{-1}$ on average at B3LYP and M06-2X). These values are negative in both phases, therefore the adsorption of 5-FL on PAMAMG0 is spontaneous and the dispersion corrections in aqueous solution emerge as attractive forces. Comparing these values with the values obtained from other sources that examined the interaction of PAMAM nanocarrier with other molecules, shows that the values of $G_{\text {binding }}$ are in the same range [74-77]. The values of the binding free energies indicate that the 5-FL drug is loading well on the PAMAMG0 carrier because $G_{\text {binding }}$ is anindicator of drug loading [78, 79].

It is observed that $G_{\text {binding }}$ depends on the orientation of 5-FL relative to PAMAMG0. As shown by both B3LYP and M06-2X levels and both phases, among 5 structures, PAMAMG0/5-FL1 is the most stable ones where the NH functional group of 5-FL interacts with the $\mathrm{CO}$ functional groups of PAMAMG0 (Fig. 2). According to our research, PAMAMG0/5-FL4 and PAMAMG0/5-FL3

Table 1. Binding $\left(\Delta G_{\text {binding }}\right)$ and solvation $\left(\Delta G_{\text {solv }}\right)$ free energies in $\mathrm{kJ} \mathrm{mol}^{-1}$ for optimized geometries

\begin{tabular}{|c|c|c|c|c|c|c|}
\hline Species & $\begin{array}{c}\Delta G_{\text {binding }}^{\text {B3LYP }} \\
\text { gas }\end{array}$ & $\begin{array}{c}\Delta G_{\text {binding }}^{B 3 L Y P} \\
\mathrm{H}_{2} \mathrm{O}\end{array}$ & $\begin{array}{c}\Delta G_{\text {binding }}^{M 062 X} \\
\text { gas }\end{array}$ & $\begin{array}{c}\Delta G_{\text {binding }}^{M 062 X} \\
\mathrm{H}_{2} \mathrm{O}\end{array}$ & $\Delta G_{\text {solv }}^{B 3 L Y P}$ & $\Delta G_{\text {solv }}^{M 062 x}$ \\
\hline PAMAMG0/5-FL1 & -82.53 & -44.91 & -77.68 & -71.57 & -120.70 & -124.08 \\
\hline PAMAMG0/5-FL2 & -12.83 & -9.05 & -23.32 & -17.95 & -154.54 & -124.82 \\
\hline PAMAMG0/5-FL3 & -71.25 & -83.93 & -25.14 & -24.25 & -122.73 & -129.29 \\
\hline PAMAMG0/5-FL4 & -51.88 & -32.40 & -59.74 & -61.46 & -138.83 & -131.91 \\
\hline PAMAMG0/5-FL5 & -68.38 & -36.01 & -70.84 & -69.62 & -125.94 & -128.97 \\
\hline
\end{tabular}
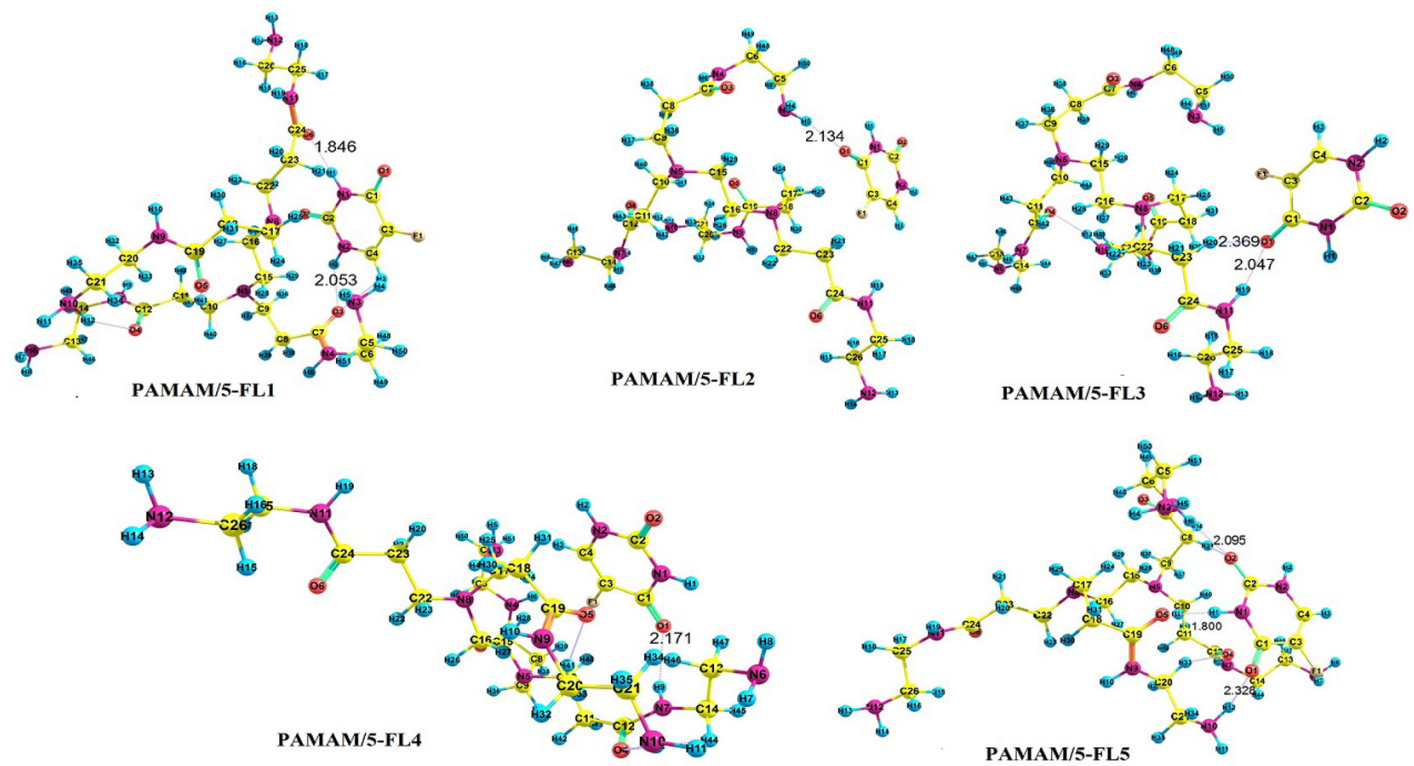

Fig. 2. Optimized structures of PAMAMG0/5-FL1-5 
configurations in terms of stability and in the aqueous solution are located in the second and third positions, respectively.

Using the following equation, the solvation free energies $\left(\Delta G_{\text {solv }}\right)$ have been assessed (Table 1):

$$
\Delta G_{s o l v}=G_{a g}-G_{g a s}
$$

In which $G_{a g}$ and $G_{g a s}$ demonstrate the free energies in the aqueous solution and gas phase, respectively. The large negative values of solvation free energies of PAMAMG0/5-FL1-5 demonstrate that the solvation process is spontaneousand it signifies the solubility of PAMAMG0/5-FL1-5 configuration in solution phase.

Table 2 depicts the quantum molecular descriptors includingglobal hardness $(\eta)$, electrophilicity power $(\omega)$ and $E_{g}$ (energy gap between LUMO and HOMO) for 5-FL, PAMAMG0 and PAMAMG0/5FL1-5 in aqueous solution and gas phase at M06-2X and B3LYP levels.

As shown in the Table 2, $E_{g}$ and $\eta$ values of 5-FL and PAMAMG0 are almostthe same. They were decreased in PAMAMG0/5-FL1-5 structures. In other words, there may be aninsignificant charge transfer between the carrier and the drug. This may be perfect for a drug delivery system, because 5-FL drug can be easily released from the exterior surface of the PAMAMG0 carrier. $E_{g}$ and $\eta$ values of PAMAMG0/5-FL1 is more than other structures, showing that it is more stable than other structures. Toxicity prediction using $\omega$ showed thatthe toxicity of 5-FL drug is decreased near the PAMAMG0 carrier. The $\omega$ values of PAMAMG0/5-FL1-5 are higher than those of 5-FL, indicating that 5-FL is the electron acceptor in these configurations.

Table 2. Quantum molecular descriptors (eV) for optimized geometries

\begin{tabular}{|c|c|c|c|c|c|c|c|c|c|c|c|}
\hline Species & $\mathrm{E}_{\text {Номо }}$ & $\mathrm{E}_{\text {LUMO }}$ & $\mathrm{Eg}$ & $\eta$ & $\omega$ & Species & $\mathrm{E}_{\text {HОМо }}$ & $\mathrm{E}_{\text {LUMO }}$ & $\mathrm{Eg}$ & $\eta$ & $\omega$ \\
\hline & \multicolumn{5}{|c|}{ B3LYP-H2O } & & \multicolumn{5}{|c|}{ M06-2X-H2O } \\
\hline PAMAMG0 & -5.44 & -4.48 & 6.04 & 3.02 & 0.97 & PAMAMG0 & -7.09 & 1.79 & 8.88 & 4.44 & 0.79 \\
\hline $5-\mathrm{FL}$ & -6.61 & -1.23 & 5.38 & 2.69 & 2.86 & & -8.07 & -0.12 & 7.95 & 3.98 & 2.11 \\
\hline PAMAMG0/5-FL1 & & -0.99 & 4.41 & 2.20 & 2.31 & PAMAMG0/5-FL1 & & 0.05 & 7.14 & 3.57 & 1.74 \\
\hline PAMAMG0/5-FL2 & -5.40 & -1.37 & 4.04 & 2.02 & 2.84 & PAMAMG0/5-FL2 & -7.04 & -0.28 & 6.76 & 3.38 & 1.99 \\
\hline PAMAMG0/5-FL3 & -5.33 & -1.33 & 4.00 & 2.00 & 2.77 & PAMAMG0/5-FL3 & -7.11 & -0.43 & 6.68 & 3.34 & 2.13 \\
\hline PAMAMG0/5-FL4 & -5.55 & -1.32 & 4.23 & 2.11 & 2.79 & PAMAMG0/5-FL4 & -7.32 & -0.21 & 7.11 & 3.56 & 1.99 \\
\hline \multirow[t]{2}{*}{ PAMAMG0/5-FL5 } & -5.45 & -1.26 & 4.19 & 2.10 & 2.68 & PAMAMG0/5-FL5 & -7.11 & 0.02 & 7.13 & 3.57 & 1.76 \\
\hline & \multicolumn{4}{|c|}{ B3LYP-GAS } & & \multicolumn{6}{|c|}{ M06-2X-GAS } \\
\hline PAMAMG0 & -5.04 & 0.75 & 5.79 & 2.90 & 0.79 & PAMAMG0 & -6.91 & 1.45 & 8.36 & 4.18 & 0.89 \\
\hline $5-\mathrm{FL}$ & -6.79 & -1.39 & 5.40 & 2.70 & 3.10 & $5-\mathrm{FL}$ & -8.25 & -0.26 & 7.99 & 4.00 & 2.26 \\
\hline PAMAMG0/5-FL1 & -5.31 & -0.40 & 4.73 & 2.37 & 1.62 & PAMAMG0/5-FL1 & -6.89 & 0.23 & 7.13 & 3.56 & 1.56 \\
\hline PAMAMG0/5-FL2 & -4.86 & -1.78 & 3.08 & 1.54 & 3.58 & PAMAMG0/5-FL2 & -6.77 & -0.65 & 6.12 & 3.06 & 2.25 \\
\hline PAMAMG0/5-FL3 & -5.37 & -1.01 & 4.36 & 2.18 & 2.33 & PAMAMG0/5-FL3 & -6.98 & -0.93 & 6.05 & 3.02 & 2.59 \\
\hline PAMAMG0/5-FL4 & -5.14 & -1.37 & 3.78 & 1.89 & 2.81 & PAMAMG0/5-FL4 & -6.71 & -0.64 & 6.07 & 3.04 & 2.22 \\
\hline PAMAMG0/5-FL5 & -5.09 & -1.16 & 3.93 & 1.97 & 2.48 & PAMAMG0/5-FL5 & -6.73 & -0.24 & 6.49 & 3.24 & 1.87 \\
\hline
\end{tabular}




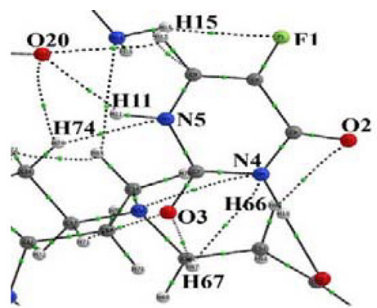

PAMAMG0/5-FL1

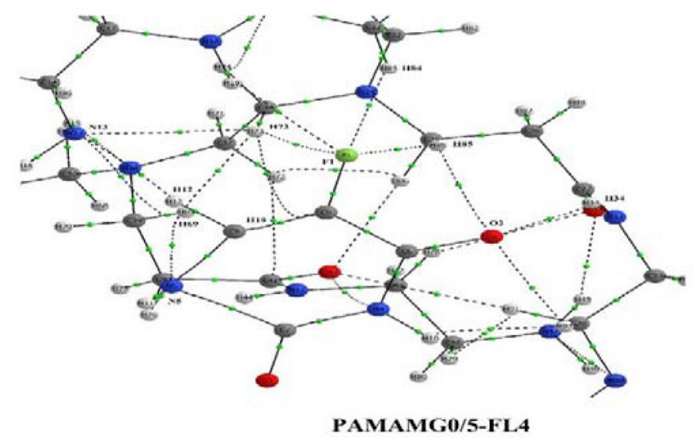

PAMAMG0/5-FL2
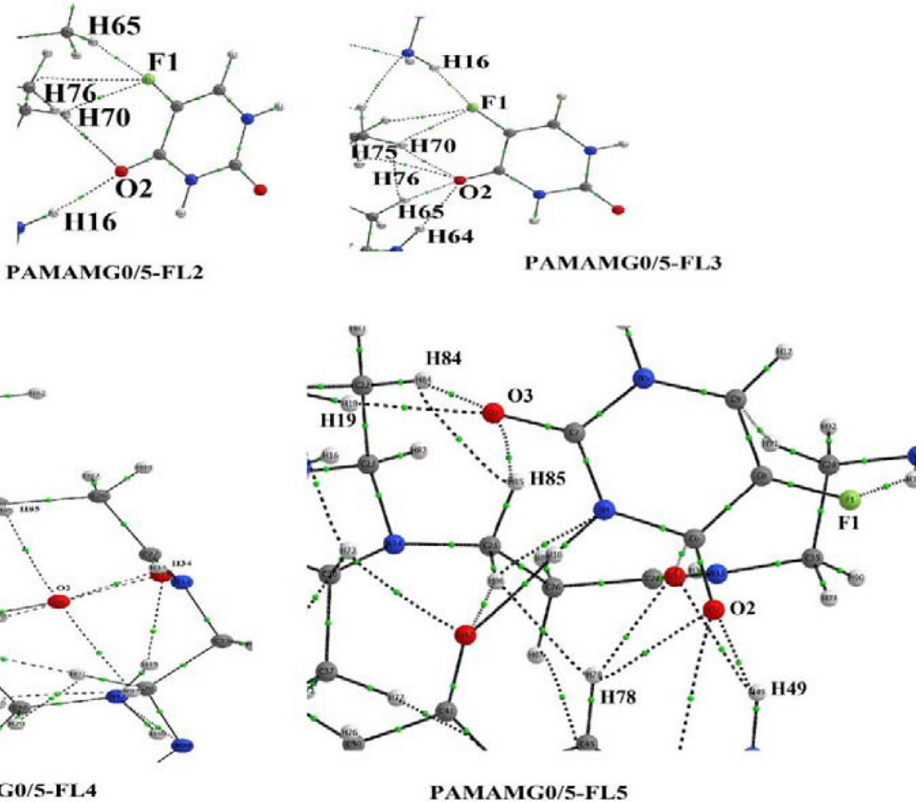

Fig. 3. Molecular graph of PAMAMG0/ 5-FL1-5. Small green spheres and lines related to the bond critical points (BCP) and the bond paths, respectively

For exploring the intermolecular hydrogen bonds in detail, we used the charge density properties. In addition, we utilized QTAIM analysis to study the interactions. The strength and characteristic of an interactioncan be determined by $\rho(\mathrm{r})$ and $\nabla^{2} \rho(\mathrm{r})$, respectively [80]. In other words, it is possible to show the interactions by the signs of $\nabla^{2} \rho$ and $H_{b}$. If, $\left(\nabla^{2} \rho>0, H_{b}>0\right),\left(\nabla^{2} \rho>0, H_{b}<0\right)$ and $\left(\nabla^{2} \rho<0\right.$, $\left.H_{b}<0\right)$, weak, medium and strong interactions are expected, respectively.

In addition, $-G_{b} / V_{b}$ demonstrates the characteristics of an interaction. Moreover $-G_{b} / V_{b}>1$ and $0.5<-G_{b} / V_{b}<1$ explain noncovalent and partially covalent characters, respectively. Figure 4 shows the molecular graphs of PAMAMG0/5-FL1-5 in aqueous solution at M06-2X/6-31G(d,p). In these Figures, the atoms included in the interaction of the drug with the carrier are marked. Table 3 shows the values of $\nabla^{2} \rho(\mathrm{r}), \rho(\mathrm{r}),-G_{b} / V_{b}$ and $H_{b}, G_{b}$ and $V_{b}$ for these interactions at M06-2X level in aqueous solution. The following equation was used toassess the hydrogen bond energies $\left(E_{H B}\right)$.

$$
E_{H B}=\frac{1}{2 V_{b}} \text {. }
$$

We observed three major types of hydrogen bonds (O-H, N-H, F-H) in PAMAMG0/5-FL1-5 structures. First, the most stable structure (PAMAMG0/5-FL1) was evaluated for this purpose, where the NH functional group of 5-FL approaches CO functional groups of PAMAMG0. The H10...O57 $\left(\mathrm{E}_{\mathrm{HB}}=-33 \mathrm{~kJ} \mathrm{~mol}^{-1}\right)$ interactions with, and $0.5<-G_{b} / V_{b}<1$ lead tomedium hydrogen bonds and the $(\mathrm{H} 95 \ldots \mathrm{N} 35)$ with $-\mathrm{G}_{\mathrm{b}} / \mathrm{V}_{\mathrm{b}}=0.9824$ may be close to strong hydrogen bonds. Furthermore, the N5...H74, $\mathrm{F} 1 \ldots \mathrm{H} 15, \mathrm{H} 11 \ldots \mathrm{O} 20, \mathrm{O} 3 \ldots \mathrm{H} 71, \mathrm{~N} 4 \ldots \mathrm{H} 67, \mathrm{O} 3 \ldots \mathrm{H} 67$ and $\mathrm{O} 2 \ldots \mathrm{H} 66$ interactions $\left(\mathrm{E}_{\mathrm{HB}}\right.$ (average) $=$ $=-10.57 \mathrm{~kJ} \mathrm{~mol}^{-1}$ ) with $\nabla^{2} \rho>0, H_{b}>0$ and $-G_{b} / V_{b}>1$ result in weak hydrogen bonds.

We found that PAMAMG0/5FL4-5 structures have similar stability. In these configurations CO functional group of 5-FL interacts with $\mathrm{NH}$ functional groups of PAMAMG0. PAMAMG0/5FL4 
Table 3. Topological parameters in a.u. and the hydrogen bond energy $\left(E_{H B}\right)$ in $\mathrm{kJ} \mathrm{mol}^{-1}$ for PAMAMG0/5-FL1-5 at M06-2X in aqueous solution

\begin{tabular}{|c|c|c|c|c|c|c|c|}
\hline Atoms & $\rho(\mathrm{r})$ & $\nabla_{\rho}^{2}(\mathrm{r})$ & $G_{b}$ & $V_{b}$ & $H_{b}$ & $-G_{b} / V_{b}$ & $E_{H B}$ \\
\hline & & & \multicolumn{2}{|c|}{ PAMAMG0/5-FL1 } & & & \\
\hline N5 - H74 & 0.0108 & 0.0342 & 0.0077 & -0.0068 & 0.0009 & 1.1258 & -8.9666 \\
\hline $\mathrm{F} 1-\mathrm{H} 15$ & 0.0076 & 0.0346 & 0.0074 & -0.0062 & 0.0012 & 1.1917 & -8.1888 \\
\hline $\mathrm{H} 11-\mathrm{O} 20$ & 0.0205 & 0.0716 & 0.0177 & -0.0174 & 0.0002 & 1.0140 & -22.8302 \\
\hline $\mathrm{O} 3-\mathrm{H} 71$ & 0.0100 & 0.0333 & 0.0076 & -0.0070 & 0.0007 & 1.0981 & -9.1200 \\
\hline N4 - H67 & 0.0077 & 0.0307 & 0.0063 & -0.0049 & 0.0014 & 1.2888 & -6.3711 \\
\hline $\mathrm{H} 10-\mathrm{O} 57$ & 0.0324 & 0.0969 & 0.0247 & -0.0251 & -0.0004 & 0.9824 & -32.9193 \\
\hline $\mathrm{O} 3-\mathrm{H} 67$ & 0.0084 & 0.0284 & 0.0064 & -0.0058 & 0.0007 & 1.1176 & -7.5502 \\
\hline \multirow[t]{2}{*}{$\mathrm{O} 2-\mathrm{H} 66$} & 0.0116 & 0.0385 & 0.0090 & -0.0084 & 0.0006 & 1.0746 & -10.9705 \\
\hline & & & \multicolumn{2}{|c|}{ PAMAMG0/5-FL2 } & & & \\
\hline $\mathrm{O} 2-\mathrm{H} 76$ & 0.0085 & 0.0299 & 0.0066 & -0.0057 & 0.0009 & 1.1516 & -7.5331 \\
\hline $\mathrm{O} 2-\mathrm{H} 16$ & 0.0156 & 0.0527 & 0.0130 & -0.0128 & 0.0002 & 1.0133 & -16.8302 \\
\hline $\mathrm{F} 1-\mathrm{H} 70$ & 0.0071 & 0.0330 & 0.0068 & -0.0054 & 0.0014 & 1.2682 & -7.0518 \\
\hline $\mathrm{O} 2-\mathrm{H} 70$ & 0.0083 & 0.0306 & 0.0066 & -0.0055 & 0.0011 & 1.1926 & -7.2433 \\
\hline \multirow[t]{2}{*}{$\mathrm{F} 1-\mathrm{H} 65$} & 0.0096 & 0.0391 & 0.0089 & -0.0081 & 0.0008 & 1.1045 & -10.6085 \\
\hline & & & \multicolumn{2}{|c|}{ PAMAMG0/5-FL3 } & & & \\
\hline $\mathrm{O} 2-\mathrm{H} 70$ & 0.0066 & 0.0248 & 0.0053 & -0.0043 & 0.0009 & 1.2206 & -5.6420 \\
\hline $\mathrm{F} 1-\mathrm{H} 70$ & 0.0077 & 0.0355 & 0.0074 & -0.0058 & 0.0015 & 1.2603 & -7.6538 \\
\hline F1 - H16 & 0.0097 & 0.0394 & 0.0091 & -0.0084 & 0.0007 & 1.0879 & -10.9849 \\
\hline $\mathrm{F} 1-\mathrm{H} 76$ & 0.0078 & 0.0354 & 0.0075 & -0.0061 & 0.0014 & 1.2283 & -7.9738 \\
\hline $\mathrm{O} 2-\mathrm{H} 75$ & 0.0080 & 0.0309 & 0.0065 & -0.0053 & 0.0012 & 1.2276 & -6.9666 \\
\hline $\mathrm{O} 2-\mathrm{H} 65$ & 0.0122 & 0.0390 & 0.0094 & -0.0090 & 0.0004 & 1.0393 & -11.8531 \\
\hline \multirow[t]{2}{*}{$\mathrm{O} 2-\mathrm{H} 64$} & 0.0197 & 0.0610 & 0.0156 & -0.0160 & -0.0004 & 0.9758 & -21.0006 \\
\hline & & & \multicolumn{2}{|c|}{ PAMAMG0/5-FL4 } & & & \\
\hline N5 - H69 & 0.0149 & 0.0561 & 0.0122 & -0.0104 & 0.0018 & 1.1765 & -13.6066 \\
\hline $\mathrm{H} 12-\mathrm{N} 13$ & 0.0200 & 0.0508 & 0.0134 & -0.0141 & -0.0007 & 0.9497 & -18.5010 \\
\hline F1 - H19 & 0.0094 & 0.0389 & 0.0089 & -0.0081 & 0.0008 & 1.1024 & -10.5915 \\
\hline $\mathrm{F} 1-\mathrm{H} 84$ & 0.0119 & 0.0466 & 0.0110 & -0.0103 & 0.0007 & 1.0649 & -13.5161 \\
\hline $\mathrm{F} 1-\mathrm{H} 85$ & 0.0088 & 0.0358 & 0.0079 & -0.0068 & 0.0011 & 1.1552 & -8.9639 \\
\hline $\mathrm{O} 2-\mathrm{H} 85$ & 0.0069 & 0.0229 & 0.0050 & -0.0043 & 0.0007 & 1.1731 & -5.5843 \\
\hline $\mathrm{O} 2-\mathrm{H} 92$ & 0.0096 & 0.0327 & 0.0073 & -0.0065 & 0.0008 & 1.1283 & -8.5233 \\
\hline $\mathrm{O} 2-\mathrm{H} 34$ & 0.0152 & 0.0548 & 0.0131 & -0.0124 & 0.0006 & 1.0498 & -16.3239 \\
\hline $\mathrm{N} 5-\mathrm{H} 76$ & 0.0115 & 0.0379 & 0.0083 & -0.0071 & 0.0012 & 1.1674 & -9.2970 \\
\hline \multirow[t]{2}{*}{$\mathrm{F} 1-\mathrm{H} 73$} & 0.0048 & 0.0216 & 0.0043 & -0.0032 & 0.0011 & 1.3544 & -4.1377 \\
\hline & & & \multicolumn{2}{|c|}{ PAMAMG0/5-FL5 } & & & \\
\hline $\mathrm{O} 3$ - H19 & 0.0161 & 0.0558 & 0.0137 & -0.0134 & 0.0003 & 1.0203 & -17.5725 \\
\hline $\mathrm{O} 3-\mathrm{H} 84$ & 0.0127 & 0.0403 & 0.0098 & -0.0095 & 0.0003 & 1.0308 & -12.4446 \\
\hline $\mathrm{O} 3-\mathrm{H} 85$ & 0.0090 & 0.0327 & 0.0070 & -0.0059 & 0.0011 & 1.1909 & -7.7574 \\
\hline F1 - H30 & 0.0107 & 0.0432 & 0.0101 & -0.0094 & 0.0007 & 1.0734 & -12.3580 \\
\hline $\mathrm{H} 10-\mathrm{O} 42$ & 0.0320 & 0.1123 & 0.0266 & -0.0251 & 0.0015 & 1.0584 & -32.9823 \\
\hline $\mathrm{O} 2$ - H79 & 0.0094 & 0.0372 & 0.0080 & -0.0067 & 0.0013 & 1.1901 & -8.8433 \\
\hline $\mathrm{O} 2-\mathrm{H} 78$ & 0.0077 & 0.0285 & 0.0061 & -0.0052 & 0.0010 & 1.1891 & -6.7816 \\
\hline $\mathrm{O} 2-\mathrm{H} 49$ & 0.0127 & 0.0435 & 0.0104 & -0.0099 & 0.0005 & 1.0497 & -12.9639 \\
\hline
\end{tabular}


has 1 medium hydrogen bond with $\mathrm{E}_{\mathrm{HB}}=-18.5 \mathrm{~kJ} \mathrm{~mol}^{-1}$ and $-\mathrm{G}_{\mathrm{b}} / \mathrm{V}_{\mathrm{b}}=0.9497$, the attributes of which

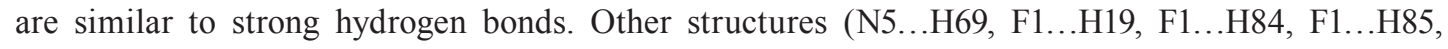
$\mathrm{O} 2 \ldots \mathrm{H} 92, \mathrm{O} 2 \ldots \mathrm{H} 85, \mathrm{O} 2 \ldots \mathrm{H} 34, \mathrm{~N} 5 \ldots \mathrm{H} 76$, and F1..H73) are arranged as weak hydrogen bonds. PAMAMG0/5FL5 has two interactions whose characteristics are close to the medium hydrogen bonds (H10...O42, H19...O3) and the other six interactions are weak.

The third most stable configuration is PAMAMG0/5-FL3. The O2...H64 $\left(\mathrm{E}_{\mathrm{HB}}=-21 \mathrm{~kJ} \mathrm{~mol}^{-1}\right)$ interaction with, $0.5<-G b / V b<1$ is medium hydrogen bonds and six other including $\mathrm{O} 2 \ldots \mathrm{H} 70$, $\mathrm{F} 1 \ldots \mathrm{H} 70, \mathrm{~F} 1 \ldots \mathrm{H} 16, \mathrm{~F} 1 \ldots \mathrm{H} 76, \mathrm{O} 2 \ldots \mathrm{H} 75, \mathrm{O} 2 \ldots \mathrm{H} 65$ are weak. PAMAMG0/5-FL2 has the most unstable structure with $\mathrm{E}_{\mathrm{HB}}$ (average) $=-9.28 \mathrm{~kJ} \mathrm{~mol}^{-1}$.

\section{Conclusions}

This work explored five structures of noncovalent adsorption of 5-fluorouracil (5-FL) drug on poly(amidoamine) G0 generation dendrimer (PAMAMG0) at B3LYP and M06-2X density functional levels in gas and aqueous solution phase (PAMAMG0/5-FL1-5). By interaction of two CO functional groups of PAMAMG0 with NH functional group of 5-FL simultaneously, it leads to the most stable structure (PAMAMG0/5-FL1).

Given the values of solvation and binding free energies, the functionalization of PAMAMG0 with 5-fluorouracil drug would be suitable in energies. The average value of $\Delta G_{\text {binding }}$ calculated at M06-2X functional is more negative than those of B3LYP in solution phase. Unlike B3LYP, dispersion corrections are considered by M06-2X functional. Considering $\Delta G_{\text {solv }}$ of PAMAMG0/5-FL1-5, it is observed that the solvation process is spontaneous. The HOMO-LUMO energy gap indicated that the global hardness and the toxicity of 5-FL in PAMAMG0/5-FL1-5 decreased. Furthermore, considering the AIM studies, 5-FL can be non-covalently functionalized on PAMAMG0/5-FL through hydrogen and pseudo-hydrogen bonds. The outcomes demonstrated that the most stable structures leads to stronger and more hydrogen bonds (PAMAMG0/5-FL1).

\section{References}

1. Chauhan A.S. Dendrimers for Drug Delivery. Molecules 2018. Vol. 23(4), P. 938-947.

2. Marasini N., Haque S., Kaminskas L.M. Polymer-drug conjugates as inhalable drug delivery systems: A review. Current Opinion in Colloid \& Interface Science 2017. Vol. 31(5), P. 18-29.

3. Pattni B.S., Chupin V.V., Torchilin V.P. New developments in liposomal drug delivery. Chemical reviews 2015. Vol. 115(19), P. 10938-10966.

4. Raza K., Thotakura N., Kumar P., Joshi M., Bhushan S., Bhatia A., Kumar V., Malik R., Sharma G., Guru S.K. C60-fullerenes for delivery of docetaxel to breast cancer cells: a promising approach for enhanced efficacy and better pharmacokinetic profile. International Journal of Pharmaceutics 2015. Vol. 495(1), P. 551-559.

5. Naiafi M. Antioxidant Activity of Sesamol Derivatives and Their Drug Delivery via C60 Nanocage: a Theoretical Study. Chinese Journal of Structural Chemistry 2019. Vol. 38(2), P. 195200.

6. Spencer D.S., Puranik A.S., Peppas N.A. Intelligent nanoparticles for advanced drug delivery in cancer treatment. Current opinion in chemical engineering 2015. Vol. 7(2), P. 84-92. 
7. Khorram R., Morsali A., Raissi H., Hakimi M., Beyramabadi S.A. Mechanistic, Energetic and Structural Aspects of the Adsorption of Carmustine on the Functionalized Carbon Nanotubes. Chinese Journal of Structural Chemistry 2017. Vol. 36(10), P. 1639-1646.

8. Kamel M., Raissi H., Morsali A., Shahabi M. Assessment of the adsorption mechanism of Flutamide anticancer drug on the functionalized single-walled carbon nanotube surface as a drug delivery vehicle: An alternative theoretical approach based on DFT and MD. Applied Surface Science 2018. Vol. 434(5), P. 492-503.

9. Kabanov A. Biomedical applications of nano-sized polymeric micelles and polyion complexes. Journal of Siberian Federal University. Biology 2018. Vol. 11(2), P. 110-118.

10. Gozde E., Kuzmina A.M., Murueva A.V., Shishatskaya E.I., Nesrin H., Vasif H. Fate of Poly-3Hydroxybutyrate-co3-Hydroxyvalerate on Skin. Journal of Siberian Federal University. Biology 2012. Vol. 5(4), P. 404-416.

11. Jansen J.F., Meijer E., de Brabander-van den Berg E.M. The dendritic box: shape-selective liberation of encapsulated guests. Journal of the American Chemical Society 1995. Vol. 117(15), P. 4417-4418.

12. Zimmerman S.C., Zeng F., Reichert D.E., Kolotuchin S.V. Self-assembling dendrimers. Science 1996. Vol. 271(5252), P. 1095-1098.

13. Alsehli M., Al-Raqa S.Y., Kucukkaya I., Shipley P.R., Wagner B.D., Abd-El-Aziz A.S. Synthesis and photophysical properties of a series of novel porphyrin dendrimers containing organoiron complexes. Journal of Inorganic and Organometallic Polymers and Materials 2019. Vol. 29(2), P. 628-641.

14. Huang D., Wu D. Biodegradable dendrimers for drug delivery. Materials Science and Engineering: C 2018. Vol. 90(3), P. 713-727.

15. Ghaffari M., Dehghan G., Abedi-Gaballu F., Kashanian S., Baradaran B., Dolatabadi J.E.N., Losic D. Surface functionalized dendrimers as controlled-release delivery nanosystems for tumor targeting. European Journal of Pharmaceutical Sciences 2018. Vol. 122(9) P. 311-330.

16. Arseneault M., Wafer C., Morin J.-F. Recent advances in click chemistry applied to dendrimer synthesis. Molecules 2015. Vol. 20(5), P. 9263-9294.

17. Alamdari N.H., Alaei-Beirami M., Shandiz S.A.S., Hejazinia H., Rasouli R., Saffari M., Ebrahimi S.E.S., Assadi A., Ardestani M.S. $\mathrm{Gd}^{3+}$-asparagine-anionic linear globular dendrimer second-generation G2 complexes: novel nanobiohybrid theranostics. Contrast media \& molecular imaging 2017. Vol. 35(1), P. 1-19.

18. Gupta A., Dubey S., Mishra M. Unique Structures, Properties and Applications of Dendrimers. Journal of Drug Delivery and Therapeutics 2018. Vol. 8(6-s), P. 328-339.

19. Patil A.A., Maiti S., Adivarekar R.V. The use of poly (amido) amine dendrimer in modification of cotton for improving dyeing properties of acid dye. International Journal of Clothing Science and Technology 2019. Vol. 31(2), P. 220-231.

20. Kirkpatrick G.J., Plumb J.A., Sutcliffe O.B., Flint D.J., Wheate N.J. Evaluation of anionic half generation 3.5-6.5 poly (amidoamine) dendrimers as delivery vehicles for the active component of the anticancer drug cisplatin. Journal of Inorganic Biochemistry 2011. Vol. 105(9), P. 1115-1122.

21. Lim J., Simanek E.E. Triazine dendrimers as drug delivery systems: From synthesis to therapy. Advanced drug delivery reviews 2012. Vol. 64(9), P. 826-835.

22. Neerman M.F., Chen H.-T., Parrish A.R., Simanek E.E. Reduction of drug toxicity using dendrimers based on melamine. Molecular Pharmaceutics 2004. Vol. 1(5), P. 390-393. 
23. Du L., Jin Y., Yang J., Wang S., Wang X. A functionalized poly (amidoamine) nanocarrierloading 5-fluorouracil: $\mathrm{pH}$-responsive drug release and enhanced anticancer effect. Anti-cancer drugs 2013. Vol. 24(2), P. 172-180.

24. Malik N., Evagorou E.G., Duncan R. Dendrimer-platinate: a novel approach to cancer chemotherapy. Anti-cancer drugs 1999. Vol. 10(8), P. 767-776.

25. Yellepeddi V.K., Kumar A., Maher D.M., Chauhan S.C., Vangara K.K., Palakurthi S. Biotinylated PAMAM dendrimers for intracellular delivery of cisplatin to ovarian cancer: role of SMVT. Anticancer Research 2011. Vol. 31(3), P. 897-906.

26. Zhu S., Hong M., Zhang L., Tang G., Jiang Y., Pei Y. PEGylated PAMAM dendrimerdoxorubicin conjugates: in vitro evaluation and in vivo tumor accumulation. Pharmaceutical research 2010. Vol. 27(1), P. 161-174.

27. Kono K., Kojima C., Hayashi N., Nishisaka E., Kiura K., Watarai S., Harada A. Preparation and cytotoxic activity of poly (ethylene glycol)-modified poly (amidoamine) dendrimers bearing adriamycin. Biomaterials 2008. Vol. 29(11), P. 1664-1675.

28. Muniswamy V.J., Raval N., Gondaliya P., Tambe V., Kalia K., Tekade R.K. 'DendrimerCationized-Albumin'encrusted polymeric nanoparticle improves BBB penetration and anticancer activity of doxorubicin. International Journal of Pharmaceutics 2019. Vol. 555(4), P. 77-99.

29. Gajbhiye V., Kumar P.V., Tekade R.K., Jain N. PEGylated PPI dendritic architectures for sustained delivery of $\mathrm{H} 2$ receptor antagonist. European journal of medicinal chemistry 2009. Vol. 44(3), P. 1155-1166.

30. Majoros I.J., Thomas T.P., Mehta C.B., Baker J.R. Poly (amidoamine) dendrimer-based multifunctional engineered nanodevice for cancer therapy. Journal of Medicinal Chemistry 2005. Vol. 48(19), P. 5892-5899.

31. Devarakonda B., Hill R.A., de Villiers M.M. The effect of PAMAM dendrimer generation size and surface functional group on the aqueous solubility of nifedipine. International Journal of Pharmaceutics 2004. Vol. 284(1-2), P. 133-140.

32. Lim J., Lo S.-T., Hill S., Pavan G.M., Sun X., Simanek E.E. Antitumor activity and molecular dynamics simulations of paclitaxel-laden triazine dendrimers. Molecular Pharmaceutics 2012. Vol. 9(3), P. 404-412.

33. Xie Y., Yao Y. Incorporation With Dendrimer-Like Biopolymer Leads to Improved Soluble Amount and In Vitro Anticancer Efficacy of Paclitaxel. Journal of pharmaceutical sciences 2019. Vol. 108(6), P. 1984-1990.

34. Morgan M.T., Carnahan M.A., Immoos C.E., Ribeiro A.A., Finkelstein S., Lee S.J., Grinstaff M.W. Dendritic molecular capsules for hydrophobic compounds. Journal of the American Chemical Society 2003. Vol. 125(50), P. 15485-15489.

35. Morgan M.T., Nakanishi Y., Kroll D.J., Griset A.P., Carnahan M.A., Wathier M., Oberlies N.H., Manikumar G., Wani M.C., Grinstaff M.W. Dendrimer-encapsulated camptothecins: increased solubility, cellular uptake, and cellular retention affords enhanced anticancer activity in vitro. Cancer research 2006. Vol. 66(24), P. 11913-11921.

36. Wang F., Bronich T.K., Kabanov A.V., Rauh R.D., Roovers J. Synthesis and evaluation of a star amphiphilic block copolymer from poly ( $\varepsilon$-caprolactone) and poly (ethylene glycol) as a potential drug delivery carrier. Bioconjugate Chemistry 2005. Vol. 16(2), P. 397-405. 
37. Fröhlich T., Hahn F., Belmudes L., Leidenberger M., Friedrich O., Kappes B., Couté Y., Marschall M., Tsogoeva S.B. Synthesis of Artemisinin-Derived Dimers, Trimers and Dendrimers: Investigation of Their Antimalarial and Antiviral Activities Including Putative Mechanisms of Action. Chemistry-A European Journal 2018. Vol. 24(32), P. 8103-8113.

38. Pedro-Hernández L.D., Martínez-Klimova E., Martínez-Klimov M.E., Cortez-Maya S., Vargas-Medina A.C., Ramírez-Ápan T., Hernández-Ortega S., Martínez-García M. Anticancer Activity of Resorcinarene-PAMAM-Dendrimer Conjugates of Flutamide. Anti-Cancer Agents in Medicinal Chemistry (Formerly Current Medicinal Chemistry-Anti-Cancer Agents) 2018. Vol. 18(7), P. 993-1000.

39. Scutaru A.M., Wenzel M., Scheffler H., Wolber G., Gust R. Optimization of the N-Lost Drugs Melphalan and Bendamustine: Synthesis and Cytotoxicity of a New Set of Dendrimer - Drug Conjugates as Tumor Therapeutic Agents. Bioconjugate Chemistry 2010. Vol. 21(10), P. 1728-1743.

40. Soni N., Jain K., Gupta U., Jain N. Controlled delivery of Gemcitabine Hydrochloride using mannosylated poly (propyleneimine) dendrimers. Journal of Nanoparticle Research 2015. Vol. 17(11), P. 458.

41. Nabavizadeh F., Fanaei H., Imani A., Vahedian J., Amoli F.A., Ghorbi J., Sohanaki H., Mohammadi S.M., Golchoobian R. Evaluation of nanocarrier targeted drug delivery of capecitabinepamam dendrimer complex in a mice colorectal cancer model. Acta Medica Iranica 2016. Vol. 10(3) P. 485-493.

42. Neerman M.F. The efficiency of a PAMAM dendrimer toward the encapsulation of the antileukemic drug 6-mercaptopurine. Anti-cancer drugs 2007. Vol. 18(7), P. 839-842.

43. Maciel D., Guerrero-Beltrán C., Ceña-Diez R., Tomás H., Muñoz-Fernández M.Á., Rodrigues J. New anionic poly (alkylideneamine) dendrimers as microbicide agents against HIV-1 infection. Nanoscale 2019. Vol. 11(19), P. 9679-9690.

44. Guerrero-Beltran C., Rodriguez-Izquierdo I., Serramia M.J., Araya-Durán I., MárquezMiranda V., Gomez R., De La Mata F.J., Leal M., González-Nilo F., Muñoz-Fernández M.A. Anionic carbosilane dendrimers destabilize the GP120-CD4 complex blocking HIV-1 entry and cell to cell fusion. Bioconjugate chemistry 2018. Vol. 29(5), P. 1584-1594.

45. Sepúlveda-Crespo D., Ceña-Díez R., Jiménez J.L., Ángeles Muñoz-Fernández M. Mechanistic studies of viral entry: an overview of dendrimer-based microbicides as entry inhibitors against both HIV and HSV-2 overlapped infections. Medicinal research reviews 2017. Vol. 37(1), P. 149-179.

46. Aliev G., AshrafG.M., Tarasov V.V., Chubarev V.N., Leszek J., Gasiorowski K., Makhmutova A., Baeesa S.S., Avila-Rodriguez M., Ustyugov A.A. Alzheimer's Disease - Future Therapy Based on Dendrimers. Current Neuropharmacology 2019. Vol. 17(3), P. 288-294.

47. Wasiak T., Marcinkowska M., Pieszynski I., Zablocka M., Caminade A.-M., Majoral J.-P., Klajnert-Maculewicz B. Cationic phosphorus dendrimers and therapy for Alzheimer's disease. New Journal of Chemistry 2015. Vol. 39(6), P. 4852-4859.

48. Klajnert B., Cangiotti M., Calici S., Majoral J.P., Caminade A.M., Cladera J., Bryszewska M., Ottaviani M.F. EPR study of the interactions between dendrimers and peptides involved in Alzheimer's and prion diseases. Macromolecular Bioscience 2007. Vol. 7(8), P. 1065-1074.

49. Solassol J.M., Crozet C., Perrier V., Leclaire J., Beranger F., Caminade A.-M., Meunier B., Dormont D., Majoral J.-P., Lehmann S. Cationic phosphorus-containing dendrimers reduce prion 
replication both in cell culture and in mice infected with scrapie. Journal of General Virology 2004. Vol. 85(6), P. 1791-1799.

50. Yiyun C., Na M., Tongwen X., Rongqiang F., Xueyuan W., Xiaomin W., Longping W. Transdermal delivery of nonsteroidal anti-inflammatory drugs mediated by polyamidoamine (PAMAM) dendrimers. Journal of Pharmaceutical Sciences 2007. Vol. 96(3), P. 595-602.

51. Yiyun C., Tongwen X. Dendrimers as potential drug carriers. Part I. Solubilization of nonsteroidal anti-inflammatory drugs in the presence of polyamidoamine dendrimers. European journal of medicinal chemistry 2005. Vol. 40(11), P. 1188-1192.

52. Bohr A., Tsapis N., Andreana I., Chamarat A., Foged C., Delomenie C., Noiray M., El Brahmi N., Majoral J.-P., Mignani S. Anti-inflammatory effect of anti-TNF- $\alpha$ siRNA cationic phosphorus dendrimer nanocomplexes administered intranasally in a murine acute lung injury model. Biomacromolecules 2017. Vol. 18(8), P. 2379-2388.

53. Castonguay A., Ladd E., van de Ven T.G., Kakkar A. Dendrimers as bactericides. New Journal of Chemistry 2012. Vol. 36(2), P. 199-204.

54. Ladd E., Sheikhi A., Li N., van de Ven T., Kakkar A. Design and synthesis of dendrimers with facile surface group functionalization, and an evaluation of their bactericidal efficacy. Molecules 2017. Vol. 22(6), P. 868.

55. Heredero-Bermejo I., Hernández-Ros J.M., Sánchez-García L., Maly M., Verdú-Expósito C., Soliveri J., de la Mata F.J., Copa-Patiño J.L., Pérez-Serrano J., Sánchez-Nieves J. Ammonium and guanidine carbosilane dendrimers and dendrons as microbicides. European Polymer Journal 2018. Vol. 101 P. 159-168.

56. Saikia N., Deka R.C. Adsorption of isoniazid and pyrazinamide drug molecules onto nitrogendoped single-wall carbon nanotubes: an ab initio study. Structural Chemistry 2014. Vol. 25(2), P. 593605.

57. Chegini H., Morsali A., Bozorgmehr M., Beyramabadi S. Theoretical study on the mechanism of covalent bonding of dapsone onto functionalised carbon nanotubes: effects of coupling agent. Progress in Reaction Kinetics and Mechanism 2016. Vol. 41(4), P. 345-355.

58. Laletina S.S., Shor E.A., Mamatkulov M.I., Yudanov I.V., Kaichev V.V., Bukhtiyarov V.I. Theoretical Study of the Methanol Dehydrogenation on Platinum Nanocluster. Journal of Siberian Federal University. Chemistry 2016. Vol. 9(4), P. 430-442.

59. Avarand S., Morsali A., Heravi M.M., Beyramabadi S.A. Structural and Mechanistic Studies of $\gamma$-Fe2O3 Nanoparticle as Hydroxyurea Drug Nanocarrier. Orbital: The Electronic Journal of Chemistry 2019. Vol. 11(3), P. 161-167.

60. Kamel M., Raissi H., Morsali A. Theoretical study of solvent and co-solvent effects on the interaction of Flutamide anticancer drug with Carbon nanotube as a drug delivery system. Journal of Molecular Liquids 2017. Vol. 248(3), P. 490-500.

61. Shahabi D., Tavakol H. DFT, NBO and molecular docking studies of the adsorption of fluoxetine into and on the surface of simple and sulfur-doped carbon nanotubes. Applied Surface Science 2017. Vol. 420(8), P. 267-275.

62. Naderi S., Morsali A., Bozorgmehr M.R., Beyramabadi S.A. Mechanistic, energetic and structural studies of carbon nanotubes functionalised with dihydroartemisinin drug in gas and solution phases. Physics and Chemistry of Liquids 2018. Vol. 56(5), P. 610-618. 
63. Avramov P.V., Kuzubov A.A., Fedorov A.S., Serzhantova M.V., Kuzik V.R. Strong Electron Correlations Determine the Stability and Properties of Er-doped Silicon Quantum Dots. Journal of Siberian Federal University. Chemistry 2010. Vol. 3(1), P. 12-19.

64. Longley D.B., Harkin D.P., Johnston P.G. 5-fluorouracil: mechanisms of action and clinical strategies. Nature reviews cancer 2003. Vol. 3(5), P. 330-335.

65. Lee J.J., Beumer J.H., Chu E. Therapeutic drug monitoring of 5-fluorouracil. Cancer chemotherapy and pharmacology 2016. Vol. 78(3), P. 447-464.

66. Espinosa E., Souhassou M., Lachekar H., Lecomte C. Topological analysis of the electron density in hydrogen bonds. Acta Crystallographica Section B: Structural Science 1999. Vol. 55(4), P. 563-572.

67. Frisch M., Trucks G., Schlegel H., Scuseria G., Robb M., Cheeseman J., Scalmani G., Barone V., Mennucci B., Petersson G. Gaussian 09, Revision B. 01 [Computer Software], Gaussian, Inc. Google Scholar, Wallingford, CT, USA, 2010

68. Tomasi J., Persico M. Molecular interactions in solution: an overview of methods based on continuous distributions of the solvent. Chemical Reviews 1994. Vol. 94(7), P. 2027-2094.

69. Coitiño E.L., Tomasi J., Cammi R. On the evaluation of the solvent polarization apparent charges in the polarizable continuum model: a new formulation. Journal of Computational Chemistry 1995. Vol. 16(1), P. 20-30.

70. Parr R.G., Szentpaly L.V., Liu S. Electrophilicity index. Journal of the American Chemical Society 1999. Vol. 121(9), P. 1922-1924.

71. Keith T.A. AIMAll (Version 13. 05. 06). TK Gristmill Software: Overland Park, KS, USA 2013.

72. Bader R.F. Atoms in molecules. Accounts of Chemical Research 1985. Vol. 18(1), P. 9-15.

73. Zhao Y., Truhlar D.G. The M06 suite of density functionals for main group thermochemistry, thermochemical kinetics, noncovalent interactions, excited states, and transition elements: two new functionals and systematic testing of four M06-class functionals and 12 other functionals. Theoretical Chemistry Accounts 2008. Vol. 120(1-3), P. 215-241.

74. Vergara-Jaque A., Comer J., Monsalve L., González-Nilo F.D., Sandoval C. Computationally efficient methodology for atomic-level characterization of dendrimer-drug complexes: a comparison of amine-and acetyl-terminated PAMAM. The Journal of Physical Chemistry B 2013. Vol. 117(22), P. 6801-6813.

75. Molla M.R., Rangadurai P., Pavan G.M., Thayumanavan S. Experimental and theoretical investigations in stimuli responsive dendrimer-based assemblies. Nanoscale 2015. Vol. 7(9), P. 3817-3837.

76. Maingi V., Kumar M.V.S., Maiti P.K. PAMAM dendrimer-drug interactions: effect of $\mathrm{pH}$ on the binding and release pattern. The Journal of Physical Chemistry B 2012. Vol. 116(14), P. 4370-4376.

77. Jain V., Maiti P.K., Bharatam P.V. Atomic level insights into realistic molecular models of dendrimer-drug complexes through MD simulations. The Journal of Chemical Physics 2016. Vol. 145(12), P. 124902-15.

78. Geetha P., Sivaram A.J., Jayakumar R., Mohan C.G. Integration of in silico modeling, prediction by binding energy and experimental approach to study the amorphous chitin nanocarriers for cancer drug delivery. Carbohydrate Polymers 2016. Vol. 142(3), P. 240-249.

79. Lin S.-H., Cui W., Wang G.-L., Meng S., Liu Y.-C., Jin H.-W., Zhang L.-R., Xie Y. Combined computational and experimental studies of molecular interactions of albuterol sulfate with bovine 
serum albumin for pulmonary drug nanoparticles. Drug Design, Development and Therapy 2016. Vol. 10(2), P. 2973-2987.

80. Rozas I., Alkorta I., Elguero J. Behavior of ylides containing N, O, and C atoms as hydrogen bond acceptors. Journal of the American Chemical Society 2000. Vol. 122(45), P. 11154-11161. 